\title{
Designing a mechanism of staff motivation in the framework of crisis management for socially responsible enterprises
}

\author{
Larysa Yankovska , Halyna Kovbas **
}

Received: 2021-09-07

Accepted: 2021-11-03

DOI: http:// doi.org/ 10.46489/lbsh.2021-1-3-4

\begin{abstract}
When a crisis occurs, managers are obliged to take measures to minimize losses. However, some of these measures may be detrimental to employee motivation, which is a problem for socially responsible enterprises. This problem threatens sustainable development, creating inequality and loss of decent working conditions on a global scale. To solve this problem, we proposed to use the mechanism of staff motivation in the framework of crisis management. We briefly described the objectives, performers, tools and expected results from the implementation of the mechanism. We also discussed the limitations of using a non-systemic stimulus method known as the "whip and gingerbread" method during a crisis. The results presented in the article will be helpful to managers of enterprises to improve management strategies and policies in a crisis.
\end{abstract}

Keywords: anti-crisis management, staff motivation, motivation tools, management mechanism, social responsibility.

\footnotetext{
${ }^{*}$ Larysa Yankovska, DSc, Professor, Honored Worker of Education of Ukraine, Chancellor, Lviv university of business and law, Kulparkivska, 99, 79021 Lviv, Ukraine, e-mail: larisalubp@gmail.com, ORCID: http://orcid.org/0000-0003-1855-0169 (corresponding author).

** Halyna Kovbas, PhD, Center for Distance Learning «Chernivtsi Institute» IAPM, Central Sq., 7, 58000 Chernivtsi, Chernivtsi, Ukraine, ORCID: https://orcid.org/0000-0002-6034-7247
} 


\section{INTRODUCTION}

Socially responsible enterprises are the backbone of sustainable development. They ensure economic growth, which is a condition for sustainable development and introduce socially sustainable practices useful for stakeholders (Scholtens, 2008).

Observation of the work of enterprises in crisis conditions and managers' reaction to challenges proves the existence of difficulties in achieving the effectiveness of staff motivation in times of crisis even. An unavoidable conflict of interest accompanies this process. The critical question is not just strategic but valueconceptual - more urgent, staff motivation or anti-crisis measures? Is it possible to coordinate the actions of motivational and crisis management? How to minimize potential losses and achieve a competitive advantage in a changing environment? To answer these questions, we propose applying the mechanism of staff motivation in the framework of crisis management (from now on - SMFCM) in socially responsible enterprises seeking sustainable development.

The modern theory of human resource management is developing in line with the concept of sustainable development (Kramar, 2017). At the same time, researchers mainly consider companies that operate under normal conditions (Hauff, 2017). On the other hand, researchers in crisis management do not pay enough attention to human resource management (Tarasova, 2019; Karas, 2018). However, the motivation of staff in a crisis has significant differences from normal conditions (Elexa, 2019).

In this article, we aim to design a mechanism that will ensure during the crisis to motivate employees to achieve personal goals and objectives of the organization, increase productivity, synergy, loyalty and organizational culture, overcoming personnel threats and turnover of qualified personnel.

\section{Methods}

In preparation for writing this article, we proceeded from the position that the management of staff motivation should be subordinated to crisis management tasks. Task of crisis management is an early response to any changes in the external and internal environment of the enterprise, which at least to some extent negatively or positively affect the enterprise's activities (Scholes, 2000). Thus, we have abstracted from the question of the importance of human resource management or crisis management. Instead, we systematized knowledge in both areas and proposed a hybrid solution that would allow for motivation-based procedures without compromising crisis management and vice versa.

This study is based on the theories of HRM and crisis management. The value framework is the principles and ideas of sustainable development and social responsibility of enterprises.

\section{RESULTS}

\section{Tasks and subjects of SMFCM}

Taking into account the step-by-step approach to crisis management, we can identify the main tasks of SMFCM, which are crucial for building, developing and modifying the motivation system in the enterprise:

- development of plans of motivational measures in case of external socioeconomic, political and legal, ecological and internal financial, production, communication, client, personnel crises;

- monitoring of the internal and external environment of the enterprise according to specific criteria for timely detection of crisis signals and response to them by the timely implementation of changes in the motivation system;

- organization and support of employees' motivation to counteract crisis processes, establishing communications, finding ways to minimize risks, including before the central crisis;

- ensuring the motivation of employees to seek external sources of assistance in overcoming the crisis, including additional funding, new customers and partners, government support, expertise;

- minimization of the consequences of the crisis to motivate staff and reduce the time of post-crisis recovery of regular operation of the enterprise.

The subjects of anti-crisis management are management staff who, within their powers (McMahon, 1989), with the appropriate 
experience and skills, can make decisions and ensure their implementation to achieve the enterprise's security. In this case, the object of crisis management should be considered enterprise systems that tend to function normally but go into an unstable state due to the crisis (Nazarova, 2010).

Following the outlined goals and objectives of SMFCM, we can identify the subjects of the mechanism, which include the management of the enterprise and employees. The object is the process of motivating staff in the framework of crisis management.

\section{Principles of the mechanism}

The achievement of the goals and objectives of SMFCM depends on the valueconceptual framework of management (Otero Mateo, 2015), which determines the feasibility of highlighting the principles of SMFCM. The tenets of SMFCM should harmonize with the principles of personnel management and crisis management.

The principles of crisis management are the rules of conduct, according to which specific management tasks are carried out, the management potential is increased, and the organization of relations of the object of management with the environment of its functioning is improved (Yepifanova, 2016). L.A. Zveruk and N.M. Davydenko, based on a systems approach, proposed such principles as the principle of constant preventive action and preparedness to respond, urgency and adequacy of response, the complexity of decisions, alternative measures and adaptability of management, the priority of internal resources, optimization of external rehabilitation and efficiency (Zveruk, 2017).

Along with this, the principles of the motivational mechanism include purposefulness; compliance of resource provision of the purpose; stability and dynamism (Yepifanova, 2016); systematicity; stimulation; continuity of development; unity of action; elasticity; innovation; economy; complexity; balance of interests (Zalohina, 2004).

Thus, we can offer such groups of SMFCM principles as:

\section{General:}

a) fairness - the functioning of the mechanism is designed to ensure the creation of equal opportunities for employees based on non-discrimination and approximation to the reference level of leading companies (Adams, 1995);

b) timeliness - the implementation of the mechanism should take place following the strategic plan of the enterprise and the motivational tools used - to meet the requirements of the time (Cooper, 1994);

c) purposefulness and expediency - managers should focus exclusively on achieving the goals of the organization, which is implemented based on the harmonization of individual and collective goals; they also should avoid insufficient or excessive measures to motivate staff that do not meet the set goals (Rothacker, 2014);

d) system and sequence - actions and decisions on staff motivation within the mechanism should be consistent with the overall and anti-crisis strategy of the enterprise, executed in a logical sequence, and interconnected and with the purpose and objectives of the mechanism.

\section{Anti-crisis:}

a) flexibility - managers must be prepared for immediate modification or transformation of the motivation system in the event of a crisis, and employees are familiar with the specifics of the relevant processes and are inclined to accept them (Escrig-Tena, 2012);

b) communicative accessibility - all processes that take place in the field of personnel management and motivation in the framework of crisis management should be sufficiently transparent and accessible for discussion among the team (Bäckström, 2016);

c) rationality - in the framework of crisis management should be used only such a restriction of motivational tools that can be rationally justified (Czarniawska, 2020);

d) organizational training - each crisis should be considered not only as a problem that needs to be addressed immediately but also as an experience in which it is possible to obtain new information about staff motivation and use them both in regular 
operation and to improve crisis management in future (Abd Rahman, 2013);

e) anti-conflict management - when making decisions about staff motivation, should choose among the alternatives that best meet the objectives and, at the same time, reduce psychological and emotional tension in the team, smooth out conflict situations and strengthen organizational culture (Djerejian, 2006).

\section{Tools for achieving SMFCM goals}

Achieving the tasks and achieving the goal of SMFCM is realized by using several combined methods.

In contrast to the traditional approach to separating tangible and intangible motivation methods, we grouped the methods recommended for use within the mechanism into three blocks.

I. A set of traditional administrative, economic and social methods of staff motivation used to build a basic system of staff motivation (first level system), particularly attracting new employees, creating conditions to achieve goals, and improving the efficiency of personnel management (De Sousa Sabbagha, 2018). The use of these methods is necessary for any company. It is dictated by the requirement to comply with labour laws and maintain the company's competitiveness in the labour market, in particular, attracting key personnel and qualified professionals, creating normal and safe working conditions and compliance with labour protection legislation. The main tools of this block are the issuance of orders and directives, the establishment of salaries, staffing, preparation of job descriptions, mandatory contributions to insurance funds, and so on. We should note that these methods and tools determine the company's position among competitors and belonging to the type of companies engaged in implementing white, grey or shadow business model, and thus affect the overall motivation of staff and the likelihood of crises.

The primary limitations on the use of the methods of this block include the following:

- their use allows to create of the initial system of motivation, the existence of which is a condition for further effective functioning of SMFCM, but does not provide a final solution to the tasks;

- the operation of the enterprise in the grey or shadow sector can not be compensated by the implementation of quasi-methods and tools belonging to this block (for example, compensation for medical payments in the absence of official contributions to the fund of temporary disability, etc. still leave the risk of exposure and is a potential source crisis);

- The sufficiency of methods belonging to this block is evidenced by the absence of problems with attracting new qualified personnel (in the absence of a labour market crisis) and the absence of comments, reservations, or claims from regulatory authorities.

II. A set of methods of material and intangible motivation of staff focused mainly on implementing the main tasks and achieving the goals of the enterprise in the medium and short term (Yoon, 2015). The main tools of this block should include bonus systems, incentive payments, financial aid, announcements of gratitude, presentation of diplomas, certificates, gifts, career advancement, involvement in business management processes, flexible schedule, etc. The methods and tools of this unit are focused on ensuring staff motivation and the normal functioning of the enterprise, mainly in stable conditions and in times of crisis are ineffective (second level system). At the same time, their application is the basis for the effective functioning of the management system in general and the crisis management system in particular.

For the second block, it is possible to formulate the following restrictions:

- methods of this block are used to create working conditions and processes and management procedures, which are the basis for further implementation of anticrisis management measures;

- in part, the system of motivation of the second level ensures the stability of the enterprise under adverse economic conditions, but not a complete alternative to a set of methods of motivating staff in crisis management; 
- the main criterion for the effectiveness of these methods in the regular operation is the achievement of goals, and in crisis management - reducing the risk of a crisis with an internal source and creating conditions for effective use of third unit methods.

III. A set of methods used in the cascade algorithm of staff motivation by stages of crisis management (Kovbas, 2020).
These methods form the basis of motivational management in a crisis, and their selection should consider the results of empirical measurements for each company. Depending on the enterprise's type and stage of development, managers can rely on various motivational theories and methods to build (improve) the motivation system.

Possible methods for use in SMFCM according to these theories are given in the table.

Table 1

\section{Methods used in SMFCM}

\begin{tabular}{|l|l|l|}
\hline $\begin{array}{l}\text { Motivation } \\
\text { Theory }\end{array}$ & Methods & Tools \\
\hline V. Vroom & $\begin{array}{l}\text { communicative, } \\
\text { normative, axiological }\end{array}$ & $\begin{array}{l}\text { communication on the formation of a clear link between } \\
\text { the efforts of the employee and the goal, as well as on the } \\
\text { performance of work as tools for reward; establishing } \\
\text { remuneration valuable to workers in times of crisis. }\end{array}$ \\
\hline B. Skinner & $\begin{array}{l}\text { operant conditioning, } \\
\text { reinforcement of } \\
\text { behavior }\end{array}$ & $\begin{array}{l}\text { reinforcement scheme (proportional, proportional- } \\
\text { temporary, random), reinforcement of anti-crisis behavior. }\end{array}$ \\
\hline $\begin{array}{l}\text { J. Stacey } \\
\text { Adams }\end{array}$ & $\begin{array}{l}\text { motancing } \\
\text { normational tools, } \\
\text { communication }\end{array}$ & $\begin{array}{l}\text { establishment of equal remuneration for the same work, } \\
\text { restoration of fairness of remuneration, assessment of } \\
\text { conformity of remuneration to the spent efforts. }\end{array}$ \\
\hline A. Maslow & $\begin{array}{l}\text { needs assessment, } \\
\text { targeted use of } \\
\text { motivational tools }\end{array}$ & $\begin{array}{l}\text { interviewing, questionnaires, creating a motivational } \\
\text { profile of employees, determining the appropriateness of } \\
\text { remuneration to the needs of employees during the crisis. }\end{array}$ \\
\hline F. Taylor & $\begin{array}{l}\text { economic rationality, } \\
\text { labor rationing }\end{array}$ & $\begin{array}{l}\text { establishment and assessment of compliance with labor } \\
\text { standards, timing, standardization, establishment of a } \\
\text { progressive scale of remuneration and penalties. }\end{array}$ \\
\hline
\end{tabular}

* formed by the authors according to the (Brown, 1993; Catania, 1984; Cullen, 1997; Kokkoniemi, 2020; Schipper, 2008)

According to the above directions, the following methods and tools should be used (Table 2).

Table 2

Methods and tools for the above directions*

\begin{tabular}{|l|l|l|}
\hline Direction & Method & Tools \\
\hline $\begin{array}{l}\text { bonus component } \\
\text { of salary }\end{array}$ & $\begin{array}{l}\text { bonuses, bonuses, } \\
\text { participation in the } \\
\text { distribution of profits }\end{array}$ & $\begin{array}{l}\text { establishing criteria for the growth of the bonus } \\
\text { component, optimization of the bonus component based } \\
\text { on the results of achieving the goals, including anti-crisis. }\end{array}$ \\
\hline $\begin{array}{l}\text { fair distribution of } \\
\text { rewards }\end{array}$ & $\begin{array}{l}\text { communicative, } \\
\text { transparency }\end{array}$ & $\begin{array}{l}\text { ensuring transparency and clarity of the remuneration } \\
\text { system taking into account crisis conditions; evaluation, } \\
\text { maintenance of employee ratings. }\end{array}$ \\
\hline $\begin{array}{l}\text { dependence of } \\
\text { remuneration on } \\
\text { the results of work }\end{array}$ & $\begin{array}{l}\text { staff evaluation, } \\
\text { reference }\end{array}$ & $\begin{array}{l}\text { assessment of personal and group results, approximation } \\
\text { of rewards to the reference ones by industry and size of } \\
\text { the enterprise. }\end{array}$ \\
\hline career growth & $\begin{array}{l}\text { career planning, } \\
\text { organizational } \\
\text { training }\end{array}$ & $\begin{array}{l}\text { creating transparent conditions and providing equal } \\
\text { opportunities for career advancement, promoting } \\
\text { training and retraining of employees in times of crisis. }\end{array}$ \\
\hline
\end{tabular}




\begin{tabular}{|c|c|c|}
\hline $\begin{array}{l}\text { safe working } \\
\text { conditions }\end{array}$ & $\begin{array}{l}\text { normative, labor } \\
\text { protection, training } \\
\text { and response, } \\
\text { standardization, } \\
\text { ergonomics }\end{array}$ & $\begin{array}{l}\text { establishing rules and regulations on occupational safety } \\
\text { and health, training on occupational safety requirements, } \\
\text { creating emergency response procedures, implementing } \\
\text { occupational safety and health standards, compliance } \\
\text { with ergonomic requirements. }\end{array}$ \\
\hline basic salary & $\begin{array}{l}\text { regulatory, planning, } \\
\text { standards }\end{array}$ & $\begin{array}{l}\text { establishment of salaries, tariff grid, job descriptions, } \\
\text { salary growth planning, comparison with reference } \\
\text { companies }\end{array}$ \\
\hline $\begin{array}{l}\text { psychological } \\
\text { climate }\end{array}$ & $\begin{array}{l}\text { normative, } \\
\text { organizational culture, } \\
\text { conflict resolution }\end{array}$ & $\begin{array}{l}\text { establishing internal labor regulations, rules of conduct } \\
\text { and norms of organizational culture, criteria for resolving } \\
\text { conflicts, conducting corporate events, involving experts } \\
\text { in the field of industrial psychology. }\end{array}$ \\
\hline $\begin{array}{l}\text { flexible work } \\
\text { schedule }\end{array}$ & $\begin{array}{l}\text { labor rationing, } \\
\text { personnel evaluation }\end{array}$ & $\begin{array}{l}\text { assessment of the possibility of establishing a flexible } \\
\text { schedule without compromising the production process } \\
\text { in a crisis, the establishment of criteria for a flexible work } \\
\text { schedule. }\end{array}$ \\
\hline social package & $\begin{array}{l}\text { competitive and } \\
\text { compensatory social } \\
\text { package }\end{array}$ & $\begin{array}{l}\text { rewards in the form of season tickets for physical culture } \\
\text { and health, cultural events, discounts, company car, } \\
\text { compensation for fuel and lubricants, communications, } \\
\text { etc. }\end{array}$ \\
\hline team spirit & $\begin{array}{l}\text { methods of } \\
\text { organizational } \\
\text { psychology }\end{array}$ & $\begin{array}{l}\text { corporate events, stimulation of team work, trainings, } \\
\text { material assistance. }\end{array}$ \\
\hline $\begin{array}{l}\text { timeliness of } \\
\text { rewards }\end{array}$ & $\begin{array}{l}\text { the method of } \\
\text { approaching the time } \\
\text { of reward to action, } \\
\text { compensation } \\
\text { method }\end{array}$ & $\begin{array}{l}\text { planning of motivational expenses in order to reduce the } \\
\text { time lag between the completed task and the reward; } \\
\text { compensation for the reduction of remuneration in the } \\
\text { crisis period by their growth in the post-crisis period. }\end{array}$ \\
\hline
\end{tabular}

* developed by the authors

\section{Expected results from the SMFCM implementation}

The expected results from the implementation of SMFCM include the following:

1. Ensuring sustainable development of the enterprise. The implementation of SMFCM involves a combination of organizational, economic and social methods that ensure the humanistic nature of management and development processes even in crisis conditions and thus meet the principles of social responsibility and are the basis of sustainable development in the long run.

2. Improving the efficiency of crisis management. The introduction of the mechanism will smooth out the "sharp corners" in motivational leadership in the transition of the enterprise from routine to crisis operation and vice versa. As a result, it will be helpful to overcome the crisis in a short time and without excessive losses and further improve the system crisis management to ensure sustainable development of the enterprise.

3. Increasing productivity in typical and crisis conditions. Reducing the risks of reduced productivity and related, particularly the loss of critical customers, inefficient use of working time, absenteeism, violation of job descriptions and labour discipline, conflicts, etc.

4. Reducing staff turnover - in particular, reducing the outflow of highly qualified personnel in a crisis, reducing the overall level of turnover, which creates the preconditions for lowering the costs associated with finding, hiring, training and adapting new employees.

5. Gaining competitive advantages associated with the accelerated exit of the enterprise from the crisis and the preservation of 
human capital and its active development in the post-crisis stage.

6. Optimization of staff motivation costs implementing the mechanism will avoid high, untargeted and inefficient costs of motivational tools, the use of which does not meet the strategy, goals and objectives of crisis management.

\section{DISCUSSION}

We must note that for the case of small (and often medium) enterprises, a typical practice is to build an intuitive system of staff motivation. Therefore, it is advisable to pay attention to the primary method that underlies intuitive motivational systems - motivation by the method of punishment and encouragement ("the method of whip and gingerbread").

We should note that this method is most often used in current and situational management (Koshovyi, 2014). The method is purely administrative. Its use does not require investment, restructuring of the personnel management system, significant qualifications or experience of the manager, etc. However, the low efficiency of this method in comparison with alternatives is assumed that from the theoretical point of view is explained by several factors:

a) the high role of subjective assessment of the actions of subordinates, which affects the increased risk of punishment or encouragement not depending on the successes or failures of work, professional qualities, but based on personal preferences of the head;

b) significant opportunities for the manager to abuse power, use subordinates in personal interests (for example, to solve private problems), corruption;

c) resources for remuneration are mostly significantly limited. At the same time, penalties are limited only to the minimum wage (in the case of a system of fines) or endurance of the manager (in the case of psychological pressure, insults, threats, etc.).

Given the existence of internal regulations (formal or informal rules), the use of such a method in small and micro enterprises is justified by its availability, flexibility and "naturalness" (intuitive nature of use), seems acceptable if it contributes to the SMFCM objectives based on outlined principles.

\section{Limitation}

The implementation of the proposed recommendations should consider the possible resistance to change on the part of the staff or even the subjects of crisis management and personnel management. This is inevitable even with a high level of trust in management decisions in personnel because any innovation challenges established traditions.

In addition, because the study is of a general theoretical nature, managers should adopt the recommendations to the needs of a particular enterprise.

\section{CONCLUSIONS}

In this article, we have outlined the general features of staff motivation in crisis management. In addition, we have briefly described the most important components of the mechanism - goals, actors, tools and expected results. This study aims to support social responsibility initiatives and business participation in sustainable development.

Communication with enterprises' managers and owners proves the constant need for new science-based tools for enterprise management. We hope that the presented material will contribute to the satisfaction of the existing demand and become the basis for further research on the issue of motivation and general personnel management in the framework of crisis management. Deepening knowledge about the nature of the crisis and making managerial decisions during the crisis will contribute to the more accurate implementation and future improvement of the proposed strategies, mechanisms and algorithms. Furthermore, the development of motivational management science can spread new practices and tools to motivate staff.

We believe that the spread of practices of conscious and rational management of enterprise motivation in times of crisis will contribute to the overall strengthening of enterprises as subjects of the single economic system of Ukraine on the path of sustainable development and European integration, improving labour protection, improving the investment climate and respect foreign partners. After all, an effective staff motivation system is 
a sign of a socially responsible enterprise, another reason to preserve labour and human potential in the context of demographic and migration crises and instability in the sociopolitical and economic environment. Furthermore, motivated employees are a constant source of innovation, becoming an essential competitive advantage of any enterprise.

Transformation of established staff motivation practices is a complex and lengthy process that requires the manager to have

\section{References}

Abd Rahman, A., Imm Ng, S., Sambasivan, M., \& Wong, F. (2013). Training and organizational effectiveness: Moderating role of knowledge management process. European Journal of Training and Development, 37(5), 472488. https://doi.org/10.1108/03090591311327 $\underline{295}$

Adams, C. A., Coutts, A., \& Harte, G. (1995). Corporate equal opportunities (non-) disclosure. The British Accounting Review, 27(2), 87-

108. https://doi.org/10.1006/bare.1994.0005

Bäckström, I., Ingelsson, P., \& Johansson, C. (2016). How communicative leadership influences co-workers' health - a quality management perspective. International Journal of Quality and Service Sciences, 8(2), 143158. https://doi.org/10.1108/IJQSS-08-2015$\underline{0059}$

Brown, F. W., \& Finstuen, K. (1993). The use of participation in decision making: $A$ consideration of the Vroom-Yetton and Vroom-Jago normative models. Journal of Behavioral Decision Making, 6(3), 207219. https://doi.org/10.1002/bdm.3960060304

Catania, A. C. (1984). The operant behaviorism of B. F. Skinner. Behavioral and Brain Sciences, 7(4), 473475. https://doi.org/10.1017/S0140525X0002 $\underline{6728}$

Cooper, R. G., \& Kleinschmidt, E. J. (1994). Determinants of Timeliness in Product Development. Journal of Product Innovation Management, 11(5), 381$396 . \quad$ https://doi.org/10.1111/1540$\underline{5885.1150381}$

Cullen, D. (1997). Maslow, Monkeys and Motivation Theory. Organization, 4(3), 355- unique competencies and attract additional resources. However, since the effectiveness of crisis management depends on the human factor, we believe that the possible costs are justified, because the introduction of the proposed organizational and economic mechanism of staff motivation will not only increase productivity in a crisis, but also solve a set of related management tasks and thus achieve socio-economic development and prosperity of the enterprise.

373. https://doi.org/10.1177/13505084974300 $\underline{4}$

Czarniawska, B. (2020). Beyond rationality in organization and managementr. Gender, Work \& Organization, 27(4), 667669. https://doi.org/10.1111/gwao.12436

De Sousa Sabbagha, M., Ledimo, O., \& Martins, N. (2018). Predicting staff retention from employee motivation and job satisfaction. Journal of Psychology in Africa, 28(2), 136140. https://doi.org/10.1080/14330237.2018.1 $\underline{454578}$

Djerejian, E. P. (2006). From Conflict Management to Conflict Resolution. Foreign Affairs,

41. https://doi.org/10.2307/20032142

Elexa, L., Hvolkova, L., \& Knapkova, M. (2019). Anticrisis management: Warning signals before failure. Marketing and Management of Innovations, $\quad 3$, 98111. https://doi.org/10.21272/mmi.2019.3-08

Escrig-Tena, A. B., Bou-Llusar, J. C., RocaPuig, V., \& Beltrán-Martín, I. (2012). Does quality management drive labour flexibility? Total Quality Management \& Business Excellence, 23(2), 159

176. https://doi.org/10.1080/14783363.2012.6 $\underline{47845}$

Hauff, S., Alewell, D., \& Katrin Hansen, N. (2017). HRM System Strength and HRM Target Achievement-Toward a Broader Understanding of HRM Processes: Strategic Human Resource Management and Organizational Ambidexterity in China. Human Resource Management, 56(5), 715729. https://doi.org/10.1002/hrm.21798

Karas, D. V., Danilchenko, Ya. V., Kryuchkov, D. V., Morozova, E. A., \& Artamonova, G. V. (2018). Quality 
management system and staff motivation. Medical

Almanac. https://doi.org/10.21145/2499-99542018-5-17-20

Kokkoniemi, M., \& Isomottonen, V. (2020). Project Education and Adams' Theory of Equity. 2020 IEEE Frontiers in Education Conference (FIE),

$1-$

5. https://doi.org/10.1109/FIE44824.2020.927 $\underline{4126}$

Koshovyi B. -P. O. (2014). Teoretychni zasady klasyfikatsii chynnykiv demotyvatsii pratsi yak zahrozy ekonomichnii bezpetsi pidpryiemstva. Naukovi rapysky Lvivskobo universytetu biznesu ta prava, 12, 142-147.

Kovbas, H. I. (2020). Stratehichni aspekty antykryzovoho upravlinnia u konteksti zabezpechennia innovatsiinoho rozvytku pidpryiemstv. Naukovi zapysky Lvivskobo universytetu biznesu ta prava, 27, 16-22. Retrieved iz https://nzlubp.org.ua/index.php/journal/art icle/view/333

Kramar, R. (2017). Sustainable HRM. In J. Syed \& R. Kramar, Human Resource Management (pp. 379-398). Macmillan Education UK. $\quad$ https://doi.org/10.1057/978-1-137$\underline{52163-7 \quad 17}$

McMahon, C. (1989). Managerial Authority. Ethics, 100(1), 3353. https://doi.org/10.1086/293143

Nazarova H. (2010). Peredumovy stvorennia systemy kadrovoi bezpeky pidpryiemstv. Rehionalni aspekty rozyytku produktywnykh syl Ukrainy, 15, 34-37.

Otero Mateo, M., Pastor Fernandez, A., \& Portela Nuñez, J. M. (2015). La creación de valor a través de la dirección y gestión de proyectos. Dyna ingenieria e industria, 90(3), 1818. https://doi.org/10.6036/7182

Rothacker, A., \& Hauer, G. (2014). Leadership in Multinational Management - A Behavior-Set to Motivate Multicultural Teams.
Procedia - Social and Behavioral Sciences, 130, 226236. https://doi.org/10.1016/j.sbspro.2014.04. $\underline{027}$

Schipper, F. (2008). A Philosophical Reading of a Classic of Management and Organisation: F W Taylor. Philosophy of Management, 6(3), 2338. https://doi.org/10.5840/pom20086318

Scholes, M. S. (2000). Crisis and Risk Management. American Economic Review, 90(2), 17-21. https://doi.org/10.1257/aer.90.2.17

Scholtens, B., Cerin, P., \& Hassel, L. (2008). Sustainable development and socially responsible finance and investing. Sustainable Development, 16(3), 137140. https://doi.org/10.1002/sd.359

Tarasova, H., Zaharov, S., Vereskun, M., \& Kolosok, V. (2019). Preventive anticrisis strategy for development of industrial enterprise. Independent Journal of Management \& Production, 10(5), 1405. https://doi.org/10.14807/ijmp.v10i5.890

Yepifanova I.Yu., Oranska N.O. (2016). Sutnist antykryzovoho upravlinnia pidpryiemstva. Ekonomika $i$ suspilstvo, 2, 265-269

Yoon, H. J., Sung, S. Y., Choi, J. N., Lee, K., \& Kim, S. (2015). Tangible and Intangible Rewards and Employee Creativity: The Mediating Role of Situational Extrinsic Motivation. Creativity Research Journal, 27(4), 383-393.

https://doi.org/10.1080/10400419.2015.10882 83

Zalohina K.I. (2004). Antykryzove upravlinnia promyslovym pidpryiemstvom v umovakh perekhidnoi ekonomiky Ukrainy: authors abstract. Khmelnytskyi natsionalnyi universytet.

Zveruk L. A., Davydenko N. M. (2017). Antykryzove upravlinnia pidpryiemstvom v umovakh innovatsiinoho rozvytku. Internauka, 1(2), 69-75. 